\title{
Klasifikasi Data Microarray Menggunakan Discrete Wavelet Transform dan Extreme Learning Machine
}

\author{
Khadijah $^{* 1}$, Sri Hartati ${ }^{2}$ \\ ${ }^{1}$ Prodi S2/S3 Ilmu Komputer, FMIPA UGM, Yogyakarta \\ ${ }^{2}$ Jurusan Ilmu Komputer dan Elektronika, FMIPA, UGM, Yogyakarta \\ e-mail: *11 khadijah0303@gmail.com, ${ }^{2}$ shartati@ugm.ac.id
}

\begin{abstract}
Abstrak
Data microarray digunakan sebagai alternatif untuk diagnosa penyakit kanker karena kesulitan dalam dignosa kanker berdasarkan bentuk morfologis, yaitu perbedaan morfologis yang tipis antar jenis kanker yang berbeda. Penelitian ini bertujuan untuk membangun pengklasifikasi data microarray. Proses klasifikasi diawali dengan reduksi dimensi data microarray menggunakan DWT, dengan cara mendekomposisi sampel hingga level tertentu, kemudian mengambil nilai koefisien aproksimasi pada level tersebut sebagai fitur sampel. Fitur tersebut selanjutnya menjadi masukan untuk klasifikasi. Metode klasifikasi yang digunakan adalah ELM yang diterapkan pada RBFN. Dataset yang digunakan adalah data microarray multikelas, yaitu dataset GCM (16.063 gen, 14 kelas) dan Subtypes-Leukemia (12.600 gen, 7 kelas).

Pengujian dilakukan dengan cara membagi data latih dan data uji secara random sepuluh kali dengan proporsi data yang sama. Classifier yang dihasilkan dari penelitian ini untuk dataset GCM belum memiliki performa yang cukup baik, ditunjukkan dengan nilai akurasi sekitar $75 \% \pm 6,25 \%$ dan nilai minimum sensitivity yang masih rendah, yaitu $15 \% \pm$ 19,95\% menunjukkan bahwa sensitivity untuk tiap kelas belum merata, terdapat beberapa kelas yang sensitivity-nya masih rendah. Namun, classifier untuk dataset Subtypes-Leukemia yang memiliki jumlah kelas lebih sedikit dari dataset GCM memiliki performa yang cukup baik, ditunjukkan dengan nilai akurasi 87,68\% $\pm 2,88 \%$ dan minimum sensitivity $51,90 \% \pm 20,29 \%$.
\end{abstract}

Kata kunci-microarray, ekspresi gen, DWT, ELM, RBFN

\begin{abstract}
Microarray data is used as an alternative in cancer diagnosis because of the difficulties cancer diagnosis based on morphologis structures. Different classes of cancer usually have poor distintion of morphologis structures. The aim of this reserach is to bulid microarray data classfier. The classification process is started by reducing dimension of microarray data. The method used to reduce the microarray data dimension is DWT by decomposing the samples until certain decomposition level and then use approximation coefficients at those level as feature to classifier. Classifier used in this reserach is ELM implemeted on RBFN. Dataset used are GCM (16.063 genes, 14 classes) and Subtypes-Leukemia (12.600 genes, 7 classes).

Testing process is done by randomly dividing the training and testing data ten times with same proprotion of training and testing data. The perfomance of classifier built in this research is not so good for GCM dataset, shown by accuracy $75 \% \pm 6,25 \%$ and mean of minimum sensitivity $15 \% \pm 19,95 \%$. The low minimum sensitivity indicate that there are few classes that have low sensitivity. But the classifier for Subtypes-Leukemia dataset give better result, that is accuracy $87,68 \% \pm 2,88 \%$ and mean of minimum sensitivity $51,90 \% \pm 20,29 \%$.
\end{abstract}

Keywords - microarray, gene expression, DWT, ELM, RBFN

Received March $4^{\text {th }}$,2014; Revised January $8^{\text {th }}, 2015$; Accepted January $20^{\text {th }}, 2015$ 


\section{PENDAHULUAN}

$\mathrm{K}$ anker merupakan salah satu jenis penyakit yang berbahaya, namun diagnosa kanker bukanlah sesuatu yang mudah. Diagnosa kanker berdasarkan struktur morfologisnya memiliki kesulitan karena perbedaan morfologis yang sangat tipis untuk jenis kanker yang berbeda. Kesulitan dalam diagnosa kanker juga dapat disebabkan oleh ketidaklengkapan informasi klinis yang tersedia dari seorang pasien serta kemungkinan adanya faktor subjektivitas pada interpretasi data tersebut. Sejumlah kesulitan tersebut telah mendorong beberapa penelitian untuk menentukan jenis kanker berdasarkan tingkat ekspresi gen [1]. Tingkat ekspresi gen menunjukkan keaktifan sebuah gen di dalam sel tubuh yang diukur berdasarkan jumlah mRNA di dalam sel tubuh tersebut [2]. Tingkat ekspresi gen dalam tubuh manusia dapat diukur melalui eksperimen microarray [3]. Pola ekspresi gen dari sejumlah pasien yang telah diketahui jenis kankernya, dapat digunakan untuk memprediksikan jenis kanker pada pasien yang baru. Permasalahan tersebut disebut sebagai klasifikasi [1, 3, 4].

Permasalahan penting dalam klasifikasi data microarray adalah jumlah gen yang sangat besar, dapat mencapai puluhan ribu (high dimensional), sedangkan jumlah sampel yang terbatas, hanya berkisar puluhan atau ratusan. Hal tersebut menyebabkan perlunya reduksi dimensi pada data microarray sebelum proses klasifikasi yang bertujuan untuk menghemat waktu komputasi [3] serta menghindari overvitting pada classifier [5]. Salah satu cara untuk mereduksi data microarray adalah ekstraksi fitur menggunakan Discrete wavelet transform (DWT) [6]. DWT dapat mendekomposisi sinyal untuk memisahkan bagian sinyal yang memiliki frekuensi rendah atau large scale dengan sinyal yang memiliki frekuensi tinggi atau small scale [7]. Bagian sinyal yang berisi frekuensi rendah menggambarkan identitas atau karakteristik sinyal [8] sehingga bagian tersebut dapat mencirikan sinyal dan berpotensi digunakan sebagai fitur sinyal. Beberapa penelitian mengenai ekstraksi fitur pada data microarray menggunakan DWT telah dilakukan $[9,10,11]$ dan menunjukkan bahwa penggunaaan DWT dapat membantu classifier untuk menghasilkan akurasi lebih dari $90 \%$.

Tahap berikutnya setelah reduksi dimensi adalah klasifikasi. Berbagai penelitian mengenai klasifikasi data microarray yang terdiri atas dua kelas (klasifikasi biner) telah banyak dilakukan dan memberikan hasil yang baik $[9,10,11,12,13]$. Namun, hasil penelitian pada klasifikasi data microarray yang terdiri lebih dari dua kelas (klasifikasi multikelas) tidak sebaik pada klasifikasi biner. Hal tersebut dikarenakan semakin banyak jumlah kelas maka semakin tinggi tingkat kesulitan dalam permasalahan klasifikasi [14]. Metode SVM (support vector machine) menghasilkan akurasi yang cukup tinggi dalam permasalahan klasifikasi biner $[9,10$, $11,13,15]$, namun saat jumlah kelas bertambah, SVM tidak dapat digunakan secara langsung dan harus dimodifikasi, misalnya SVM-OVA (one-versus-all) atau SVM-OVO (one-versusone). Hal tersebut meningkatkan kompleksitas classifier sehingga membutuhkan resource komputasi yang lebih besar [16].

Extreme learning machine (ELM) dikembangkan oleh [17], yaitu algoritma pelatihan untuk single-hidden-layer feedforward neural network yang dapat mengatasi kelemahan pada gradient descent learning. ELM mampu melakukan pelatihan dalam waktu cepat karena tidak memerlukan iterasi, serta tetap menghasilkan kemampuan generalisasi yang baik [17]. Penggunaan ELM pada feedforward neural network dengan fungsi aktivasi sigmoid untuk klasifikasi data microarray multikelas telah dilakukan pada penelitian [16]. Hasilnya menunjukkan bahwa ELM mampu menghasilkan akurasi yang lebih baik daripada SVM saat jumlah kelas semakin banyak. [18] membandingkan penerapan ELM pada feedforward neural network yang menggunakan fungsi aktivasi sigmoid dengan ELM pada RBFN (radial basis function network) untuk klasifikasi data microarray dan menunjukkan bahwa ELM yang diterapkan pada RBFN dapat memberikan performa yang lebih baik. [19] mengembangkan ELM untuk generalized single-hidden-layer feedforward network (SLFN) yang memiliki performa lebih baik dibanding ELM semula dalam permasalahan [19].

Penelitian ini melakukan klasifikasi data microarray multikelas menggunakan DWT untuk ekstraksi fitur dan ELM untuk klasifikasi sebab DWT memiliki kemampuan yang baik

IJCCS Vol. 9, No. 1, January 2015 : $33-42$ 
untuk ekstraksi fitur dan ELM memiliki performa yang bagus untuk klasifikasi multikelas seperti yang telah dijelaskan sebelumnya. ELM yang digunakan adalah ELM yang dikembangkan oleh [19] dan diterapkan pada RBFN karena penggunaan ELM pada RBFN memberikan hasil yang lebih baik daripada feedforward neural network dengan additive sigmoid node [18]. Dataset microarray yang digunakan dalam penelitian ini adalah dataset GCM (14 kelas, 16.063 gen) dan Subtypes-Leukemia (7 kelas, 12.600 gen).

\section{METODE PENELITIAN}

Data microarray direpresentasikan dalam bentuk matriks ekspresi gen berukuran $m \times n$ dengan $m$ adalah banyaknya gen dan $n$ adalah banyaknya sampel. Setiap baris menunjukkan gene-expression vector, yaitu ekspresi sebuah gen tertentu pada setiap sampel dan setiap kolomnya menunjukkan sample-expression vector, yaitu ekspresi setiap gen pada sebuah sampel tertentu. Terdapat tiga tahapan dalam penelitian ini yang digunakan untuk melakukan klasifikasi data microarray seperti pada Gambar 1, yaitu prapemrosesan, ekstraksi fitur dan klasifikasi itu sendiri.

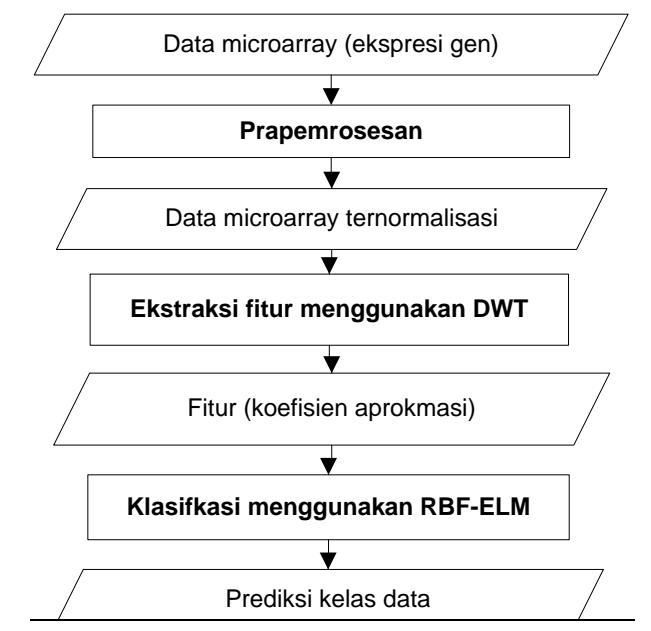

Gambar 1 Tahapan klasifikasi data microarray

\subsection{Prapemrosesan}

Prapemrosesan bertujuan untuk meminimalkan variabilitas teknis pada saat eksperimen.

\subsubsection{Prapemrosesan dataset GCM}

Langkah-langkah untuk prapemrosesan pada dataset GCM adalah:

1. Koreksi nilai ekspresi gen

Batas atas dan bawah nilai ekspresi gen diatur ke nilai tertentu seperti yang digunakan pada penelitian aslinya, [1]. Nilai ekspresi gen pada dataset yang kurang dari 20 diubah ke 20 karena nilai yang sangat kecil dapat memuat noise dan tidak reproducible, sedangkan nilai yang melebihi 16.000 dibulatkan ke 16.000 karena nilai yang sangat besar disebabkan oleh saturation effect.

2. Filtering gen

Filtering gen dilakukan untuk menghilangkan gen yang tidak mengalami perubahan nilai siginifikan di antara sampel yang ada. Cara yang digunakan untuk melakukan filtering gen sama dengan cara yang digunakan pada penelitian aslinya [1]. Gen-gen yang lolos dari filtering gen untuk digunakan pada tahap berikutnya adalah gen-gen yang memenuhi kedua syarat berikut:

a. Perbandingan nilai ekspresi maksimum dan minimum (max/min) untuk sebuah gen di antara semua sampel lebih dari atau sama dengan 5.

b. Selisih nilai mutlak ekspresi maksimum dan minimum (|max-min|) untuk sebuah gen di antara semua sampel lebih dari atau sama dengan 500. 
3. Normalisasi antar array

Normalisasi antar array dilakukan dengan cara centering, yaitu mengurangi setiap nilai intensitas setiap array dengan nilai rata-rata intensitas lalu membaginya dengan nilai standar deviasi pada array tersebut, sehingga setiap array memiliki rata-rata nilai intensitas 0 dan standar deviasi 1. Metode ini paling sering digunakan untuk normalisasi data antar array.

\subsubsection{Prapemrosesan dataset Subtypes-Leukemia}

Langkah-langkah untuk melakukan prapemrosesan pada dataset Subtypes-Leukemia adalah sebagai berikut:

1. Koreksi nilai ekspresi gen

Batas atas dan bawah nilai ekspresi gen diatur ke nilai tertentu seperti yang digunakan pada penelitian aslinya [20]. Nilai ekspresi gen kurang dari 100 dan absent call serta nilai ekspresi gen negatif diubah ke nilai 1, sedangkan nilai yang lebih dari 45.000 dibulatkan ke 45.000.

2. Filtering gen

Cara yang digunakan untuk melakukan filtering gen sama dengan cara yang digunakan pada penelitian aslinya [20]. Gen-gen diloloskan dari proses filtering gen jika memenuhi kedua syarat berikut:

a. Persentase present call $(\mathrm{P})$ untuk sebuah gen di antara semua lebih dari atau sama dengan $1 \%$.

b. Selisih nilai mutlak intensitas maksimum dan minimum (|max-min|) untuk sebuah gen di antara semua sampel lebih dari atau sama dengan 100.

3. Normalisasi antar array

Normalisasi antar array dilakukan dengan cara yang sama seperti prapemrosesan dataset GCM.

\subsection{Ekstraksi Fitur}

Ekstraksi fitur pada penelitian ini menggunakan discrete wavelet transform (DWT). DWT merupakan salah satu jenis transformasi wavelet yang melakukan pemampatan pada sinyal secara dyadic (bilangan interger pangkat dua), yaitu 2, 4, 8, 16 dan seterusnya. DWT digunakan untuk mendekomposisi sinyal ke dalam beberapa frekuensi band. Contoh ilustrasi dekomposisi pada sebuah sinyal ditunjukkan pada Gambar 2 [8]. Dekomposisi adalah pembagian sinyal menjadi dua bagian menggunakan highpass decomposition filter $(\mathrm{H})$ dan lowpass decomposition filter (L). Sinyal S dikonvolusi menggunakan filter $\mathrm{H}$, kemudian dilakukan downsampling sehingga dihasilkan koefisien detail (cD1). Sinyal $\mathrm{S}$ juga didekomposisi menggunakan filter L, kemudian dilakukan downsampling sehingga dihasilkan koefisien aproksimasi (cA1) [7]. Konvolusi sinyal $\mathrm{S}$ dengan filter $\mathrm{H}$ meloloskan daerah frekuensi tinggi dari sinyal, sehingga $\mathrm{cD} 1$ berisi bagian sinyal yang berfrekuensi tinggi. Konvolusi sinyal S dengan filter L meloloskan daerah frekuensi rendah dari sinyal, sehingga cA1 memuat daerah sinyal berfrekuensi rendah yang menggambarkan identitas sinyal. Downsampling pada hasil konvolusi menyebabkan panjang cA1 maupun cD1 menjadi kurang lebih setengah dari panjang sinyal S [8]. Daerah frekuensi rendah dari sinyal memuat informasi yang penting karena daerah tersebut menggambarkan identitas sinyal [8]. Contoh dekomposisi DWT 3 level ditunjukkan pada Gambar 3.

Setiap sampel hasil prapemrosesan didekomposisi menggunakan wavelet filter hingga level tertentu. Fitur yang digunakan selanjutnya adalah koefisien aproksimasi yang didapat pada level dekomposisi tersebut sebab koefisien aproksimasi dapat menggambarkan identitas sinyal [8]. Wavelet filter yang digunakan adalah Daubachies karena wavelet filter tersebut dapat digunakan untuk DWT dan wavelet tersebut digunakan dalam penelitian $[9,10,11,13,15]$.

Beberapa parameter yang diujicoba dalam proses ekstraksi fitur untuk mendapatkan hasil klasifikasi terbaik, yaitu tipe wavelet filter Daubechies yang digunakan dan level dekomposisi. Tipe Daubachies yang diuji coba antara lain $\mathrm{db} 2$, db4, db8 dan db10. Sejumlah kemungkinan level dekomposisi yang diujicoba yaitu dari 3, 4, 5, 6 dan 7. Pada dekomposisi 
level 2 ukuran data hanya menjadi sekitar 1/4 dari ukuran semula (ukuran data semula > 10000) sehingga percobaan dimulai dari level 3, sedangkan dekomposisi level 8 pengurangan jumlah data terlalu banyak sehingga dapat menghilangkan informasi yang penting dari data.

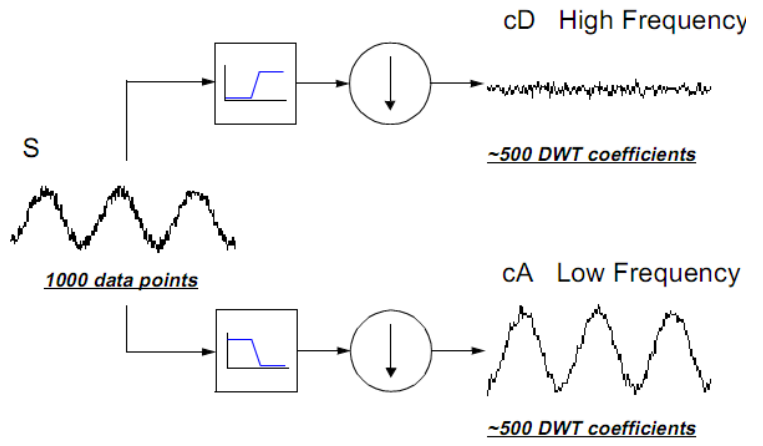

Gambar 2 Dekomposisi sinyal menggunakan DWT [8]

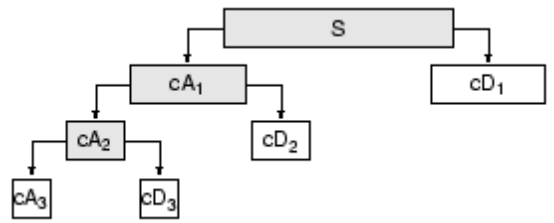

Gambar 3 Dekomposisi sinyal menggunakan DWT 3 level [8]

\subsection{Klasifikasi}

Metode klasifikasi yang digunakan adalah Extreme Learning Machine (ELM) yang diterapkan pada RBFN. Kelebihan ELM antara lain parameter hidden node dapat diinisialisasi secara random dan nilainya tidak perlu diubah-ubah selama proses pelatihan, sedangkan bobot output jaringan dapat dihitung melalui sebuah persamaan matematika, sehingga waktu pelatihan sangat singkat. ELM yang akan digunakan adalah ELM untuk generalized SLFN yang dikembangkan oleh [19]. ELM tersebut merupakan perbahruan dari ELM sebelumnya [17] dan memiliki performa yang lebih baik untuk klasifikasi.

Arsitektur jaringan yang akan digunakan untuk klasifikasi data microarray adalah RBFN seperti yang ditunjukkan pada Gambar 4. Jumlah input node adalah $d$ dengan $d$ adalah jumlah fitur atau ukuran sampel yang didapat dari hasil ekstraksi fitur. Jumlah hidden node adalah $L=1000$ sesuai dengan jumlah yang digunakan dalam penelitian [19]. Jumlah output node yang digunakan adalah $m$ dengan $m$ adalah banyaknya kelas, pada dataset GCM $m=14$, sedangkan pada dataset Subtypes-Leukemia $m=7$. Algoritma pelatihan yang digunakan adalah ELM yang dikembangkan oleh [19]. Vektor $\mathbf{a}_{j}$ adalah center dan $b_{j}$ adalah parameter scale atau width dari fungsi basis radial pada hidden node ke- $j$, sedangkan $\boldsymbol{\beta}_{j}$ adalah bobot koneksi antara sebuah hidden node ke- $j$ ke setiap output node (1. .m).

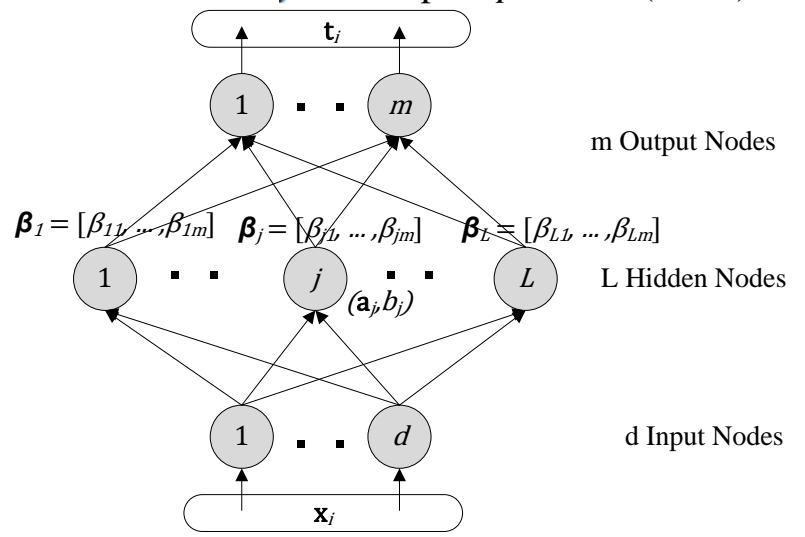

Gambar 4 Arsitektur RBFN untuk klasifikasi data microarray 
Data ekspresi gen setelah proses ekstraksi fitur terdiri atas pasangan input-output $\left(\mathbf{x}_{i}, y_{i}\right), \quad i=1_{1} \ldots, N$ dengan $N$ adalah jumlah sampel pada data latih. Vektor $\mathbf{x}_{i}=\left[x_{i 1}, x_{i 2}, \ldots, x_{i d}\right]^{T} \in \mathbf{R}^{d}$ adalah feature set dari sampel ke-i yang didapat dari proses ekstraksi fitur dan $y_{i}$ nomor kelas (jenis kanker) untuk sampel ke-i. Nilai input data $\mathbf{x}_{i}$ yang digunakan untuk pelatihan diskalakan terlebih dahulu ke rentang [-1,1] sesuai yang disarankan oleh [19]. Jumlah node yang digunakan adalah sebanyak $m$ kelas, sehingga untuk melakukan pelatihan, output $y_{i}$ dikonversi terlebih dahulu ke dalam vektor $\mathbf{t}_{i}=\left[t_{i 1}, t_{i 2}, \ldots, t_{i m}\right]^{T} \in \mathbf{R}^{m}$. Nilai pada vektor $\mathbf{t}_{i}$ yang indeksnya merupakan nomor kelas dari sampel ke-i $i\left(y_{i}\right)$ diberi nilai 1 , sedangkan nilai pada indeks lainnya adalah -1 , sebagai contoh sebuah sampel ke-i pada dataset Subtypes-Leukemia $(m=7)$ yang termasuk dalam nomor kelas $4\left(y_{i}=4\right)$ akan memiliki vektor output $\mathbf{t}_{i}=[-1,-1,-1,1,-1,-1,-1]^{T}$. Dengan demikian, pasangan data latih yang di-inputkan ke RBFN adalah $\left(\mathbf{x}_{i}, \mathbf{t}_{i}\right), i=1, \ldots, N$. Algoritma pelatihan ELM adalah sebagai berikut:

1) Men-generate parameter pada hidden node $\left(\mathbf{a}_{j}, b_{j}\right)_{j=1}^{L}$ secara random.

2) Menghitung hidden layer output matrix $\mathbf{H}$ menggunakan fungsi aktivasi hidden node $G\left(\mathbf{a}_{i}, b_{i}, \mathbf{x}\right)$ Gaussian seperti persamaan (1) atau multiquadric seperti persamaan (2)

$$
\begin{aligned}
& G\left(\mathbf{a}_{j}, b_{j}, \mathbf{x}\right)=\exp \left(-b_{j}\left\|\mathbf{x}-\mathbf{a}_{j}\right\|^{2}\right) \\
& G\left(\mathbf{a}_{j}, b_{j}, \mathbf{x}\right)=\left(\left\|\mathbf{x}-\mathbf{a}_{j}\right\|^{2}+b_{j}{ }^{2}\right)^{1 / 2}
\end{aligned}
$$

3) Bobot output $\boldsymbol{\beta}$ dihitung menggunakan persamaan (3).

$$
\begin{gathered}
\beta=\mathrm{H}^{\mathrm{T}}\left(\frac{\mathrm{I}}{C}+\mathrm{HH}^{\mathrm{T}}\right)^{-1} \mathrm{~T} \\
\mathbf{f}(\mathbf{x})=\mathbf{h}(\mathbf{x}) \boldsymbol{\beta}=\mathbf{h}(\mathbf{x}) \mathbf{H}^{\mathrm{T}}\left(\frac{\mathrm{I}}{C}+\mathrm{HH}^{\mathrm{T}}\right)^{-1} \mathrm{~T}
\end{gathered}
$$

Selanjutnya penentuan output hasil klasifikasi dihitung menggunakan persamaan (4).

\subsection{Ukuran Hasil Klasifikasi}

Ukuran yang dapat digunakan untuk mengevaluasi performa classifier pada klasifikasi multiclass adalah akurasi atau correct classification rate (AC) dan minimum sensitivity (MS). Akurasi menunjukkan kemampuan classifier untuk mengklasifikasikan dengan benar di antara semua data masukan, sedangkan minimum sensitivity menunjukkan kemampuan minimal classifier untuk mengklasifikan dengan benar di antara data yang seharusnya berada pada kelas tertentu. Langkah-langkah untuk mengukur $A C$ dan MS adalah [18] :

1) Matriks $\mathbf{P}=\left\{p_{i j} ; \sum_{i, j=1}^{m} p_{i j}=N\right\}$ disusun dengan dimensi $m \times m$ ( $m$ adalah banyaknya class-label). Nilai $p_{i j}$ menunujukkan jumlah data yang seharusnya berada pada class $i$, namun diklasifikan ke class $j$ oleh classifier dan $p_{i}=\sum_{j=1}^{m} p_{i j}$ menunjukkan jumlah data yang seharusnya berada pada class $i$.

2) Sensitivity untuk class $i$ dihitung dengan $S_{i}=p_{i i} / p_{i}$ menunjukkan perbandingan antara data yang diklasifikasikan dengan benar oleh classifier ke class $i$ dengan jumlah data yang seharusnya berada di class i. Minimum sensitivity dihitung dengan $M S=\min \left\{S_{i} ; i=1, \ldots, m\right\}$.

3) Akurasi atau correct classification rate dihitung dengan $A C=1 /{ }_{N} \sum_{j=1}^{m} p_{j j}$.

4) Classifier yang terbaik $(\widehat{g})$ di antara sejumlah classifier $\left(g_{i}\right)$ adalah classifier yang mampu ditunjukkan seperti persamaan (5). Nilai $\overline{A C_{g_{\mathrm{L}}}}$ menunjukkan rata-rata-rata nilai $A C$ dan $M S_{g_{\mathrm{i}}}$ adalah rata-rata nilai $M S$ yang didapat dari beberapa kali percobaan (cross-validation) menggunakan classifier $g_{i}[18]$. 


$$
\hat{g}=\arg \max _{g_{i}} \frac{\overline{A C_{g_{\mathrm{L}}}}+\overline{M S_{g_{\mathrm{n}}}}}{2}
$$

\subsection{Dataset}

Dataset microarray yang digunakan dalam penelitian ini adalah:

1. Dataset GCM (14 kelas, 16.063 gen), terdiri atas 144 data latih dan 46 data uji dengan distribusi data latih:data uji untuk tiap kelas adalah Breast (8:3), Prostate (8:2), Lung (8:3), Colorectal (8:3), Lymphoma (16:6), Bladder (8:3), Melanoma (8:2), Uterus_Adeno (8:2), Leukemia (24:6), Renal (8:3), Pancreas (8:3), Ovary (8:3), Mesothelioma (8:3), CNS (16:4) [1].

2. Dataset Subtypes-Leukemia (7 kelas, 12.600 gen), terdiri atas 144 data latih dan 46 data uji dengan distribusi data latih:data uji untuk tiap kelas adalah BCR-ABL (9:6), E2A-PBX1 (18:9), Hyperdiploid $>50$ (42:22), MLL (14:6), T-ALL (28:15), TEL-AML1 (52:27), Others (52:27) [20].

\subsection{Rancangan Pelatihan dan Pengujian}

Terdapat beberapa parameter yang harus ditentukan dalam algoritma klasifikasi, yaitu fungsi aktivasi dan nilai bilangan $\mathrm{C}$ untuk perhitungan bobot output jaringan. Fungsi aktivasi yang dicoba adalah Gaussian dan multiquadric, sedangkan nilai $\mathrm{C}$ yang dicoba adalah nilai-nilai dalam rentang $\left\{2^{-5}, 2^{-4}, \ldots, 2^{24}, 2^{25}\right\}$. Penentuan fungsi aktivasi dan niai $\mathrm{C}$ yang digunakan untuk mendapatkan hasil klasifikasi yang terbaik dilakukan melakukan $k$-fold cross-validation $(k=5)$ pada data latih. Nilai parameter yang memberikan hasil terbaik selanjutnya diterapkan untuk melakukan pelatihan pada semua data latih, selanjutnya model classifier yang didapat dari hasil pelatihan tersebut diterapkan untuk memprediksikan kelas pada data uji. Setelah itu, data latih dan data uji tersebut digabungkan menjadi satu, lalu dibagi secara random ke dalam jumlah data latih dan data uji dengan proporsi jumlah data per kelas yang sama. Pembagian tersebut diulang sebanyak 9 kali, kemudian proses pelatihan dan pengujian dilakukan pada masingmasing data latih dan data uji dari hasil pembagian secara random tersebut, sehingga totalnya ada 10 kali proses pengujian yang dilakukan. Hasil akhir yang dilaporkan dari penelitian ini adalah rata-rata akurasi dan minimum sensitivity yang didapat dari 10 kali pengujian tersebut.

\section{HASIL DAN PEMBAHASAN}

Proses 5-fold cross-validation dilakukan dengan mengulang tahap pelatihan dan validasi RBF-ELM sebanyak 3 kali, sehingga dalam satu cross-validation terdapat 15 kali percobaan yang dilakukan. Nilai akurasi (AC) dan minimum sensitivity (MS) dihitung darii rata-rata selama 15 kali percobaan. Setiap kali penggunaan wavelet filter, level dekomposisi dan fungsi aktivasi tertentu, dilakukan 31 kali cross-validation dengan nilai $\mathrm{C}$ yang berbeda, kemudian dipilih nilai $\mathrm{C}$ yang memberikan hasil klasfikasi terbaik. Proses 5-cross-validation pertama kali pada data latih dilakukan untuk melihat pengaruh penggunaan fungsi aktivasi dalam proses klasifikasi. Hasilnya untuk dataset GCM maupun Subtypes-Leukemia menunjukkan bahwa penggunaan fungsi aktivasi multiquadric memberikan hasil (nilai AC dan MS) yang lebih baik dibanding fungsi aktivasi Gaussian. Selanjutnya, dilakukan cross-validation menggunakan wavelet filter dan level dekomposisi yang berbeda untuk mendapatkan nilai $\mathrm{C}$ terbaik pada saat penggunaan parameter tersebut. Fungsi aktivasi dan nilai $\mathrm{C}$ yang memberikan hasil terbaik pada 5 crossvalidation selanjutnya digunakan untuk melatih seluruh data latih, hasil pelatihan kemudian diujikan pada data uji.

\subsection{Dataset GCM}

Hasil yang didapat untuk pengujian dataset GCM dengan 10 kali pengacakan data latih dan uji ditunjukkan pada Tabel 1. Hasil terbaik pada proses pengujian didapat saat menggunakan wavelet filter db8 dan level dekomposisi 5, yaitu rata-rata akurasi 75\% $\pm 6,25 \%$ dan rata-rata minimum sensitivity $15 \% \pm 19,95 \%$. Hasil tersebut sedikit lebih tinggi dari penelitian [5], yaitu 67,39\%, namun masih lebih rendah dari penelitian [16], yaitu 76,5\% \pm 
5,3\%. Minimum sensitivity yang dihasilkan pada sebagian besar percobaan memiliki nilai standar deviasi yang lebih besar dari nilai rata-ratanya menunjukkan bahwa pada percobaan yang telah dilakukan sering terdapat kelas yang tidak pernah diprediksi oleh classifier, sehingga nilai minimum sensitivity dari percobaan tersebut adalah 0 .

Tabel 1 Hasil pengujian dataset GCM

\begin{tabular}{|l|r|r|r|r|c|c|c|r|}
\hline \multicolumn{4}{|c|}{ Parameter } & \multicolumn{6}{c|}{ Pengujian } \\
\hline Filter & Level & $\begin{array}{c}\text { Jumlah } \\
\text { Fitur }\end{array}$ & C & $\begin{array}{c}\text { Mean } \\
\text { AC }\end{array}$ & $\begin{array}{c}\text { SD } \\
\text { AC }\end{array}$ & $\begin{array}{c}\text { Mean } \\
\text { MS }\end{array}$ & $\begin{array}{c}\text { SD } \\
\text { MS }\end{array}$ & $\begin{array}{c}\text { (Mean AC + } \\
\text { Mean MS) / 2 }\end{array}$ \\
\hline $\mathrm{db} 2$ & 3 & 1370 & 4 & 0,7370 & 0,0452 & 0,0667 & 0,1405 & 0,4018 \\
\hline $\mathrm{db} 2$ & 4 & 687 & 4 & 0,7152 & 0,0652 & 0,1000 & 0,1610 & 0,4076 \\
\hline $\mathrm{db} 2$ & 5 & 345 & 0 & 0,7391 & 0,0410 & 0,1333 & 0,1721 & 0,4362 \\
\hline $\mathrm{db} 4$ & 3 & 1375 & 3 & 0,7435 & 0,0596 & 0,0667 & 0,1405 & 0,4051 \\
\hline $\mathrm{db} 4$ & 4 & 691 & 4 & 0,7304 & 0,0733 & 0,0667 & 0,1405 & 0,3986 \\
\hline $\mathrm{db} 4$ & 5 & 348 & 15 & 0,6370 & 0,0481 & 0,0000 & 0,0000 & 0,3185 \\
\hline $\mathrm{db} 8$ & 3 & 1382 & 4 & 0,7326 & 0,0384 & 0,0667 & 0,1405 & 0,3996 \\
\hline $\mathrm{db} 8$ & 4 & 698 & 4 & 0,7174 & 0,0703 & 0,0667 & 0,1405 & 0,3920 \\
\hline db8 & $\mathbf{5}$ & $\mathbf{3 5 6}$ & $\mathbf{1}$ & $\mathbf{0 , 7 5 0 0}$ & $\mathbf{0 , 0 6 2 5}$ & $\mathbf{0 , 1 5 0 0}$ & $\mathbf{0 , 1 9 9 5}$ & $\mathbf{0 , 4 5 0 0}$ \\
\hline $\mathrm{db} 10$ & 3 & 1385 & 3 & 0,7478 & 0,0461 & 0,1000 & 0,1610 & 0,4239 \\
\hline $\mathrm{db} 10$ & 4 & 702 & 22 & 0,6652 & 0,0704 & 0,0667 & 0,1405 & 0,3659 \\
\hline $\mathrm{db} 10$ & 5 & 360 & 0 & 0,7196 & 0,0610 & 0,0833 & 0,1800 & 0,4014 \\
\hline
\end{tabular}

Tabel 2 Hasil pengujian dataset Subtypes-Leukemia

\begin{tabular}{|l|r|r|r|r|r|c|c|r|}
\hline \multicolumn{4}{|c|}{ Parameter } & \multicolumn{6}{|c|}{ Pengujian } \\
\hline Filter & Level & $\begin{array}{c}\text { Jumlah } \\
\text { Fitur }\end{array}$ & \multicolumn{1}{c|}{ C } & $\begin{array}{c}\text { Mean } \\
\text { AC }\end{array}$ & SD AC & $\begin{array}{c}\text { Mean } \\
\text { MS }\end{array}$ & SD MS & $\begin{array}{c}\text { (Mean AC + } \\
\text { Mean MS) / 2 }\end{array}$ \\
\hline db2 & $\mathbf{3}$ & 1353 & 18 & $\mathbf{0 , 8 9 2 9}$ & $\mathbf{0 , 0 1 6 8}$ & $\mathbf{0 , 5 1 0 6}$ & $\mathbf{0 , 2 3 3 3}$ & $\mathbf{0 , 7 0 1 7}$ \\
\hline $\mathrm{db} 2$ & 4 & 678 & 4 & 0,8848 & 0,0254 & 0,4500 & 0,1581 & 0,6674 \\
\hline $\mathrm{db} 2$ & 5 & 340 & 6 & 0,8554 & 0,0303 & 0,3833 & 0,1125 & 0,6193 \\
\hline $\mathrm{db} 4$ & 3 & 1357 & 15 & 0,8955 & 0,0246 & 0,4444 & 0,2400 & 0,6700 \\
\hline db4 & $\mathbf{4}$ & $\mathbf{6 8 2}$ & 20 & $\mathbf{0 , 8 7 6 8}$ & $\mathbf{0 , 0 2 8 8}$ & $\mathbf{0 , 5 1 9 0}$ & $\mathbf{0 , 2 0 2 9}$ & $\mathbf{0 , 6 9 7 9}$ \\
\hline $\mathrm{db} 4$ & 5 & 344 & 17 & 0,7795 & 0,0355 & 0,3741 & 0,1801 & 0,5768 \\
\hline $\mathrm{db} 7$ & 3 & 1362 & 22 & 0,8938 & 0,0247 & 0,3500 & 0,2284 & 0,6219 \\
\hline $\mathrm{db} 7$ & 4 & 687 & 20 & 0,8696 & 0,0295 & 0,3852 & 0,2271 & 0,6274 \\
\hline $\mathrm{db} 7$ & 5 & 350 & 5 & 0,8589 & 0,0234 & 0,3000 & 0,1315 & 0,5795 \\
\hline $\mathrm{db} 10$ & 3 & 1367 & 3 & 0,9036 & 0,0118 & 0,3000 & 0,2049 & 0,6018 \\
\hline $\mathrm{db} 10$ & 4 & 693 & 21 & 0,8500 & 0,0151 & 0,3167 & 0,1834 & 0,5833 \\
\hline $\mathrm{db} 10$ & 5 & 356 & 2 & 0,8902 & 0,0158 & 0,3833 & 0,1372 & 0,6368 \\
\hline
\end{tabular}

\subsection{Dataset Subtypes-Leukemia}

Hasil yang didapat untuk pengujian dataset Subtypes-Leukemia dengan 10 kali pengacakan data latih dan uji ditunjukkan pada Tabel 2. Hasil tertinggi pada proses pengujian didapat saat menggunakan wavelet filter $\mathrm{db} 2$ dan level dekomposisi 3, yaitu 0,7017. Jika diamati hasil tersebut tidak jauh berbeda dengan hasil yang didapat saat menggunakan wavelet filter db4 dan level dekomposisi 4, yaitu 0,6979, di samping itu penggunaan level dekomposisi 4 menghasilkan jumlah fitur yang lebih kecil, kurang lebih setengah kali jumlah fitur dari level

IJCCS Vol. 9, No. 1, January 2015 : $33-42$ 
dekomposisi 3, oleh karena itu disimpulkan bahwa hasil terbaik didapat saat penggunaan wavelet filter db4 dan level dekomposisi 4.

Hasil yang didapat dari penelitian ini, yaitu akurasi $87,68 \% \pm 2,88 \%$ lebih rendah dari penelitian [5], yaitu 91,07\%. Klasifikasi dataset Subtypes-Leukemia juga dilakukan oleh [17], tetapi hanya menggunakan 6 kelas, kelas terakhir yaitu kelas Others tidak digunakan. Untuk melihat perbandingan dengan penelitian [15], maka penelitian ini juga melakukan klasifikasi pada 6 kelas dataset Subtypes-Leukemia. Akurasi yang dihasilkan dari penelitian ini untuk klasifikasi dataset Subtypes-Leukemia 6 kelas adalah 97,56\% $\pm 2,66 \%$ dan minimum sensitivity $83,59 \% \pm 16,67 \%$. Hasil tersebut sedikit lebih tinggi dibanding penelitian [15], yaitu akurasi $93,68 \%$.

\section{KESIMPULAN}

Dari penelitian ini telah dibangun pengklasifikasi data microarray untuk dataset GCM dan Subtypes-Leukemia. Ekstraksi fitur dilakukan menggunakan DWT dengan wavelet filter hingga level dekomposisi tertentu, lalu menggunakan nilai koefisien aproksimasi level terakhir sebagai masukan untuk tahap klasifikasi. Klasifikasi dilakukan menggunakan RBFN dengan algoritma ELM. Hasil yang didapat untuk setiap dataset tersebut adalah sebagai berikut:

1) Hasil terbaik untuk dataset GCM, yaitu rata-rata akurasi $75 \% \pm 6,25 \%$ dan rata-rata minimum sensitivity $15 \% \pm 19,95 \%$ dicapai saat menggunakan wavelet filter db8 dan level dekomposisi 5 untuk ekstraksi fitur serta fungsi aktivasi multiquadric dan nilai $\mathrm{C}=2^{1}$ untuk algoritma pelatihan ELM. Hasil tersebut sedikit lebih tinggi dari penelitian [5], yaitu $67,39 \%$, namun masih lebih rendah dari penelitian [16], yaitu 76,5\% $\pm 5,3 \%$.

2) Hasil terbaik untuk dataset Subtypes-Leukemia, yaitu rata-rata akurasi $87,68 \% \pm 2,88 \%$ dan rata-rata minimum sensitivity $51,90 \% \pm 20,29 \%$ dicapai saat menggunakan wavelet filter db4 dan level dekomposisi 4 untuk ekstraksi fitur serta fungsi aktivasi multiquadric dan nilai $\mathrm{C}=2^{20}$ untuk algoritma pelatihan ELM. Hasil tersebut lebih rendah dari penelitian [5], yaitu $91,07 \%$. Jika dibandingkan dengan penelitian [15] menggunakan 5 cross-validation pada semua dataset dengan 6 kelas, hasil dari penelitian ini adalah 97,56\% $\pm 2,66 \%$, lebih tinggi dibanding penelitian [15], yaitu akurasi 93,68\%.

\section{SARAN}

Beberapa hal yang dapat dilakukan untuk perbaikan penelitian ini antara lain:

1) Penelitian ini dapat diujicobakan pada dataset microarray lainnya, sehingga dapat diamati hasil yang didapat pada berbagai dataset microarray yang lain.

2) Perbaikan dapat dilakukan pada proses ekstraksi fitur dengan mencoba wavelet filter lainnya atau melakukan pemrosesan lebih lanjut pada nilai koefisien hasil dekomposisi sebelum dijadikan fitur masukan classifier, agar didapat hasil klasifikasi yang lebih baik.

\section{DAFTAR PUSTAKA}

[1] Ramaswamy, S., Tamayo, P., Rifkin, R., Mukherjee, S., Yeang, C.-H., Angelo, M., Ladd, C., Reich, M., Latulippe, E., Mesirov, J.P., Poggio, T., Gerald, W., Loda, M., Lander, E.S. and Golub, T.R., 2001, Multiclass Cancer Diagnosis Using Tumor Gene-expression Signatures, Proceedings of National Academy Sciences (PNAS), USA, 98, 26, 15149 15154.

[2] Ghanem, M., 2004, Course 341 Introduction to Bioinformatics Microarrays1: Microarray Technology, Lecture Notes, Department of Computing, Imperial College, London.

[3] Stekel, D., 2003, Microarray Bioinformatics, Cambridge University Press, New York.

[4] Quackenbush, J., 2006, Microarray Analysis and Tumor Classification, New England J. Medicine, 354, 23, 2463-2472. 
[5] Wang, H., Zhang, H., Dai, Z., Chen, M. dan Yuan, Z., 2013, TSG: A New Algorithm for Binary and Multi-class Cancer Classification and Informative Genes Selection, BMC Medical Genomics 2013, 6(Suppl 1):S3.

[6] Lio, P., 2003, Wavelets in Bioinformatics and Computational Biology: State of Art and Perspectives, Bioinformatics Review, 19, 1, 2-9.

[7] Fugal, D. L., 2009, Conceptual Wavelets in Digital Signal Processing, Space and Sinyal Technical Publishing, Sandiego, California.

[8] Misiti, M., Misiti, Y., Oppenheim, G. dan Poggi, J-M., 2012, Wavelet Tollbox ${ }^{T M}$ User's Guide R2012b, The MathWork Inc., Natick.

[9] Li, S., Liao, C. and Kwok, J.T., 2006, Wavelet-Based Feature Extraction for Microarray Data Classification, Int. Joint Conference on Neural Networks, Vancouver, BC, Canada, 16-21 Juli, 5028-5033.

[10] Liu, Y., 2008, Detect Key Gene Information in Classification of Microarray Data, EURASIP J. Advances in Signal Processing, 2008, 1-10.

[11] Rashid, S. and Maruf, G.M, 2011, An Adaptive Feature Reduction Algorithm for Cancer Classification Using Wavelet Decomposition of Serum Proteomic and DNA Microarray Data, IEEE International Conference on Bioinformatics and Biomedicine Workshops (BIBM11), Atlanta, Georgia, USA, 12-15 November, 305-312.

[12] Huynh, H.T., Kim, J.J. dan Won, Y., 2007, DNA Microarray Classification with Compact Single Hidden-Layer FeedForward Neural Networks, Proceedings of Frontiers in the Convergence of Bioscience and Information Technologies, Cheju Island, Korea, 11-13 Oktober, 193-198.

[13] Zhang, S.W., Huang, D.S. and Wang, S.L., 2010, A Method of Tumor Classification Based on Wavelet Packet Transforms and Neighborhood Rough Set, Computers in Biology and Medicine, 40, 430-437.

[14] Stanikov, A., Aliferis, C.F., Tsamardinos, I., Hardin, D. dan Levy, S., 2005, A Comprehensive Evaluation of Multicategory Classification Methods for Microarray Gene Expression Cancer Diagnosis, Bioinformatics, 21, 5, 631-643.

[15] Liu, Y., 2009, Wavelet Feature Extraction for High-Dimensional Microarray Data, Neurocomputing, 72, 985-990.

[16] Zhang, R., Huang, G.B., Sundararajan, N. and Saratchandran, P., 2007, Multicategory Classification Using an Extreme Learning Machine for Microarray Gene-expression Cancer Diagnosis, IEEE/ACM Transaction on Computational Biology and Bioinformatics, 4, 3, 485-495.

[17] Huang, G.B., Zhu, Q.Y. and Siew, C.K., 2004, Extreme Learning Machine: A New Learning Scheme of Feedforward Neural Networks, Proceedings of International Joint Conference on Neural Networks (IJCNN2004), Budapest, Hungary, 25-29 Juli.

[18] Monedero, J.S., Ramirez, M.C., Navarro, F.F., Fernandez, J.C., Gutierrez, P.A. and Martinez, C.H., 2010, On the Suitability of Extreme Learning Machine for Gene Classification Using Feature Selection, Proceedings of International Conference on Intelligent Systems Design and Applications (ISDA), Cairo, 20 Nov - 1 Des, 507-512.

[19] Huang, G.B, Zhou, H., Ding, X. and Zhang, R., 2012, Extreme Learning Machine for Regression and Multiclass Classification, IEEE Transaction on System, Man, and Cybernetics - Part B: Cybernetics, 42, 2, 513-529.

[20] Yeoh, E.J., Ross, M.E., Shurtleff, S.A., Williams, W.K., Patel, D., Mahfouz, R., Behm, F.G., Raimondi, S.C., Relling, M.V., Patel, A., Cheng, C., Campana, D., Wilkins, D., Zhou, X., Li, J., Liu, H., Pui, C.H., Evans, W.E., Naeve, C., Wong, L. and Downing, J.R., 2002, Classification, Subtype Discovery, and Prediction of Outcome in Pediatric Acute Lymphoblastic Leukemia by Gene Expression Profiling, Cancer Cell, 1, 133-143.

IJCCS Vol. 9, No. 1, January 2015: $33-42$ 